\title{
ANALISIS KETEPATAN WAKTU PENGAJUAN KLAIM JAMINAN KESEHATAN NASIONAL PADA RUMAH SAKIT
}

\author{
Suhadi ${ }^{1}$ \\ ${ }^{1}$ Fakultas Kesehatan Masyarakat Universitas Halu Oleo, Kendari \\ suhaditsel77@uho.ac.id ${ }^{1}$
}

\begin{abstract}
Abstrak
Salah satu faktor permasalahan klaim yang sering menjadi hambatan dalam pencairan dana pelayanan kesehatan di rumah sakit adalah ketepatan waktu pengajuan klaim di kantor BPJS oleh pihak rumah sakit. Dalam pelaksanaan nya Rumah Sakit seringkali tidak tepat waktu dalam pengajuan klaim JKN. Adanya Kondisi pengajuan klaim yang tidak tepat waktu dan sering terlambat akan berdampak pada siklus keuangan rumah sakit. Pada keadaan yang lebih tinggi maka hal ini akan berpengaruh terhadap operasionalisasi pelayanan kesehatan di rumah sakit. Tujuan penelitian untuk menganalisis ketepatan waktu pengajuan klaim Jaminan Kesehatan Nasional di Rumah Sakit Badan Layanan Umum Bahteramas Prov. Sulawesi Tenggara Kota Kendari. Jenis penelitian kualitatif dengan pendekatan studi kasus. Informan penelitian meliputi Petugas Casemix, Verifikator BPJS, Kepala Rekam Medik, Petugas Rawat Inap dan pasien peserta JKN. Hasil penelitian menunjukkan bahwa pengajuan klaim JKN oleh Rumah Sakit Badan Layanan Umum Bahteramas Prov. Sulawesi Tenggara seringkali tidak tepat waktu, hal ini disebabkan oleh kondisi faktor internal berupa ketidaklengkapan pengisian resume medis oleh petugas, tidak adanya tanda tangan Dokter Penanggung Jawab pelayanan pada resume medis, kesalahan koding oleh petugas, kurangnya berkas penunjang tindakan medis, dan kondisi jaringan online yang sering ngadat pada saat penginputan data klaim, serta faktor ekternal dari unsur pasien yang melakukan penunggakan iuran JKN. Kesimpulan; ketepatan waktu pengajuan klaim pelayanan kesehatan oleh Rumah Sakit Badan Layanan Umum Bahteramas Prov. Sulawesi Tenggara belum sepenuhnya berjalan optimal dilakukan sehingga kondisi ini dapat menghambat pengelolaan keuangan rumah sakit di masa datang. Saran; hendaknya pihak rumah sakit melakukan pelatihan manajemen klaim JKN diikuti dengan pengawasan pengelolaan klaim, peningkatan sumber daya teknologi jaringan internet, serta peningkatan koordinasi pengelolaan klaim dengan pihak BPJS guna tercapainya efektifitas program JKN
\end{abstract}

Kata Kunci : Rumah Sakit, Ketepatan Waktu, Klaim JKN, BPJS

\begin{abstract}
One of the factors in the claim problem that often becomes an obstacle in disbursing health service funds at the hospital is the timeliness of submitting claims at the BPJS office by the hospital. In its implementation, the hospital is often not on time in submitting JKN claims. The existence of conditions for filing claims that are not timely and often late will have an impact on the financial cycle of the hospital. In higher circumstances, this will affect the operation of health services in hospitals. The research objective was to analyze the timeliness of submitting claims for National Health Insurance at the Bahteramas Prov. Southeast Sulawesi, Kendari City. This type of research is qualitative with a case study approach. Research informants include Casemix Officers, BPJS Verifiers, Head of Medical Records, Inpatient Officers and JKN participant patients. The results showed that the submission of JKN claims by the Bahteramas Prov. Southeast Sulawesi is often not on time, this is due to internal factors such as incompleteness of filling out medical resumes by officers, the absence of the signature of the Doctor in charge of services on the medical resume, errors in coding by officers, lack of supporting files for medical action, and the condition of the online network often crashes at the time of inputting claim data, as well as external factors from the patient's element of arrears for JKN contributions. Conclusion; the timeliness of submitting health service claims by the Public Service Agency Hospital Bahteramas Prov. Southeast Sulawesi has not yet fully implemented it, so this condition could hamper financial management of hospitals in the future. Suggestion; The hospital should carry out training on JKN claims management followed by supervising claims management, increasing internet network technology resources, and improving the coordination of claims management with BPJS in order to achieve the effectiveness of the JKN program.
\end{abstract}




\section{PENDAHULUAN}

Sesuai amanat Undang-Undang Nomor 40 Tahun 2004 tentang Sistem Jaminan Sosial Nasional dan Undang-Undang Nomor 24 Tahun 2011 tentang Badan Penyelenggara Jaminan Sosial Kesehatan (BPJS), BPJS Kesehatan sebagai Badan Penyelenggara merupakan badan hukum publik yang dibentuk untuk menyelenggarakan program Jaminan Kesehatan Nasional (JKN) bagi seluruh rakyat Indonesia, diamanatkan untuk mengembangkan system pelayanan kesehatan, sistem kendali mutu dan kendali biaya, serta system pembayaran pelayanan kesehatan yang efisien dan efektif guna tercapainya sustainibilitas program JKN ${ }^{1}$.

Beberapa upaya kendali mutu dan kendali biaya telah dilakukan sejak beroperasionalnya BPJS Kesehatan. Salah satu kendali biaya yang telah dilakukan adalah melalui upaya penyelesaian klaim-klaim bermasalah yang diinventarisir baik dari BPJS Kesehatan maupun dari Kementerian Kesehatan. Bentuk kesepakatan upaya penyelesaian klaim bermasalah antara BPJS Kesehatan, Kementerian Kesehatan, dan Organisasi Profesi dituangkan pertama kali dalam Surat Edaran Sekretaris Jenderal Kementerian Kesehatan Nomor HK 03.03/X/1185/2015 tentang Pedoman Penyelesaian ${ }^{1}$.

Permasalahan Klaim INA-CBG dalam Penyelenggaraan JKN yang memuat tentang 17 (tujuh belas) kasus permasalahan koding dan 18 (delapan belas) kasus permasalahan klinis. Tidak berhenti sampai di situ, penyempurnaan terhadap upaya penyelesaian permasalahan klaim terus dilakukan hingga diterbitkannya Surat Edaran Menteri Kesehatan Nomor HK.03.03/MENKES/63/2016 dan Surat Edaran Menteri Kesehatan Nomor HK.03.03/MENKES/518/2016 tentang Pedoman Penyelesaian Permasalahan Klaim INACBG dalam Penyelenggaraan JKN yang mana dalam Surat Edaran terakhir telah disepakati penyelesaian terhadap 20 (dua puluh) kasus permasalahan koding, 49 (empat puluh sembilan) kasus permasalahan klinis, serta 2 (dua) kasus permasalahan klinis dan mekanisme pengajuan klaim ${ }^{1}$.

Salah satu permasalahan yang diketahui dalam program JKN yaitu dalam proses verifikasi klaim. Berdasarkan data yang dimiliki BPJS Kesehatan per 20 Februari 2014, diketahui bahwa secara nasional sudah ada 953 rumah sakit atau fasilitas kesehatan lanjutan dari 1.750 Rumah Sakit yang bekerja sama dengan BPJS Kesehatan dan berdasarkan data tersebut, baru enam rumah sakit yang selesai dalam verifikasi klaim dan telah dibayarkan oleh BPJS Kesehatan. Berdasarkan data tersebut terlihat bahwa sebagian besar rumah sakit masih kesulitan untuk menyelesaikan proses verifikasi klaim ${ }^{2}$.

Klaim BPJS adalah pengajuan biaya perawatan pasien peserta BPJS oleh pihak rumah sakit kepada pihak BPJS Kesehatan, dilakukan secara kolektif dan ditagihkan kepada pihak BPJS Kesehatan setiap bulannya ${ }^{3}$. Fasilitas Kesehatan Rujukan Tingkat Lanjutan (FKRTL) dalam hal ini rumah sakit, berkewajiban untuk melengkapi dokumen klaim BPJS sebelum diajukan kepada pihak BPSS Kesehatan untuk mendapatkan penggantian biaya perawatan sesuai dengan tarif Indonesia Case Base Groups (INA-CBG's) ${ }^{4}$.

Salah satu faktor permasalahan klaim yang sering menjadi hambatan dalam pencairan dana pelayanan kesehatan di rumah sakit adalah ketepatan waktu pengajuan klaim di kantor BPJS oleh pihak rumah sakit. Dalam pelaksanaan nya Rumah Sakit seringkali tidak tepat waktu dalam pengajuan klaim JKN. Adanya Kondisi pengajuan klaim yang tidak tepat waktu dan sering terlambat akan berdampak pada siklus keuangan rumah sakit. Pada keadaan yang lebih tinggi maka hal ini akan berpengaruh terhadap operasionalisasi pelayanan kesehatan di rumah sakit.

Kejadian dan permasalahan klaim BPJS kesehatan pada rumah sakit sudah sering terjadi dan ini menjadi masalah yang masih dihadapi saat ini oleh pemberi pelayanan kesehatan. Kasus ini dapat dibuktikan dari beberapa hasil penelitian diantaranya ${ }^{5}$ yang mengatakan bahwa proses pelaksanaan klaim BPJS di Rumah Sakit Panti Nugroho sudah lancar tetapi masih terdapat berkas klaim yang diserahkan terlambat. Penelitian 6 mengatakan bahwa telah ditemukan berbagai kendala terkait pembiayaan berupa keterlambatan pencairan klaim akibat keterlambatan proses pemberkasan klaim dan adanya perbedaan nilai tarif pelayanan terhadap paket pelayanan INA-CBGs. Penelitian 7 mengatakan bahwa adanya pengembalian dokumen rekam medis karena kurang lengkapnya syarat untuk melakukan pengklaiman dan kurang lengkapnya pengisian dokumen rekam medis.

Rumah Sakit Badan Layanan Umum Daerah (BLUD) Bahteramas Prov. Sulawesi Tenggara, telah mengakreditasi 12 jenis pelayanan yaitu administrasi manajemen, pelayanan medik, pelayanan gawat darurat, pelayanan keperawatan, pelayanan rekam medis, pelayanan radiologi, pelayanan farmasi, pelayanan laboratorium, pelayanan peristi, pelayanan kamar operasi, pelayanan pencegahan infeks, pelayanan keselamatan dan kesehatan kerja. Saat ini statusnya menjadi Rumah Sakit Type B pendidikan dan ditetapkan sebagai RS rujukan Tingkat Lanjut 
tertinggi di Sulawesi Tenggara yang memberikan pelayanan rawat jalan, rawat inap dan pelayanan gawat darurat yang bekerja sama dengan BPJS Kesehatan ${ }^{8}$.

Dari hasil Riset awal yang dilakukan di RS BLUD Bahteramas Prov. Sultra diperoleh bahwa masih terjadi ketidaktepatan waktu pengajuam klaim klaim JKN yang diajukan oleh RS kepada pihak BPJS sehingga hal tersebut dapat menganggu siklus pembiayaan operasional pelayanan kesehatan RS, karena ketersediaan pelayanan kesehatan untuk memenuhi kebutuhan masyarakat membutuhkan dana yang cukup, salah satunya tergantung dari ketetpatan waktu pengajuan klaim JKN. Kondisi ini secara umum tidak menguntungkan rumah sakit, pada keadaan yang lebih tinggi akan menyebabkan rendahnya mutu pelayanan kesehatan bahkan menurunkan pendapatan rumah sakit.

\section{METODE}

Jenis penelitian kualitatif dengan pendekatan Studi Kasus. Informan Kunci terdiri dari dua orang Petugas Casemix, satu orang Kepala Rekam Medik dan satu orang petugas verifikator BPJS Kesehatan. Informan Biasa satu orang Petugas Ruang Rawat Inap dan satu orang pasien rawat Inap peserta JKN. Pengumpulan data dengan menggunakan observasi, wawancara mendalam dan telaah dokumen. Analisis data dengan menganalisis permasalahannya dilakukan secara deskriptif, yang lebih menekankan analisisnya pada proses penyimpulan terhadap dinamika antar fenomena yang diamati, dengan menggunakan logika dan cara-cara berfikir formal dan argumentatif (Consuelo, 1997) dalam Suhadi, (2019) ${ }^{9}$.

\section{HASIL DAN DISKUSI}

Ketepatan waktu pengajuan klaim JKN diartikan sebagai kesesuaian waktu atau tanggal bagi rumah sakit ketika mengajukan klaim JKN ke kantor BPJS berdasarkan waktu yang telah ditetapkan untuk pengumpulan berkas klaim pelayanan kesehatan. Ketetapan waktu pengajuan klaim JKN telah diatur dalam Permenkes nomor 28 tahun 2014 tentang Pedoman Pelaksanaan Program Jaminan Kesehatan Nasional yang menyatakan bahwa fasilitas kesehatan mengajukan klaim setiap bulan secara reguler paling lambat tanggal 10 bulan berikutnya.

Hasil temuan dari wawancara mendalam diperoleh bahwa keterlambatan waktu pengajuan klaim disebabkan oleh adanya faktor ketidaklengkapan berkas klaim JKN berupa ketidaklengkapan catatan medis, ketidaklengkapan rincian obat, dan keterbatasan waktu verifikasi. Adanya masalah Jaringan Internet yang sering ngadat pada saat pengimputan data klaim sehingga proses penginputan data menjadi terhambat, termasuk kurangnya pelaksanaan koordinasi antar petugas dalam penyelesaian pekerjaan. Adapun faktor lain penyebab keterlambatan pengajuan klaim dari sisi pasien yang melakukan penunggakan iuran BPJS sehingga membutuhkan waktu yang cukup didalam penyelesaiaan administrasi klaim tersebut , sebagaimana pernyataan informan berikut:

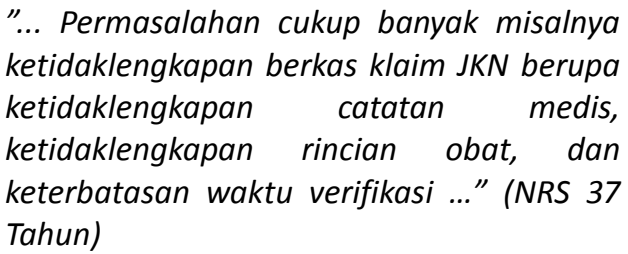

" Dalam pengamatan kami masalah itu misalnya adanya masalah Jaringan Internet yang sering ngadat pada saat pengimputan data klaim sehingga proses penginputan data menjadi terhambat, termasuk kurangnya pelaksanaan koordinasi antar petugas dalam penyelesaian pekerjaan...." (KYS 34 Tahun)

“... Banyak kendala salah satu nya berupa penyebab keterlambatan pengajuan klaim dari sisi pasien yang melakukan penunggakan iuran BPJS sehingga membutuhkan waktu yang cukup didalam penyelesaiaan administrasi klaim..." (BHR 46 Tahun)

Hasil temuan dari wawancara mendalam diperoleh pula bahwa berkas yang telah diajukan Rumah Sakit seringkali ditolak oleh pihak BPJS, hal ini terjadi karena pada berkas klaim tersebut masih terdapat kesalahan pengimputan, kendala lain berupa bukti tindakan medis yang tidak lengkap, hasil pemeriksaan penunjang medis tidak dilampirkan, ketidaksesuaian koding, dan berkas resume medis yang tidak lengkap, sebagaimana pernyataan informan sebagai berikut:

",, Kadang berkas klaim yang telah diajukan kepihak BPJS dikembalikan untuk dilakukan perbaikan, hal ini terjadi karena pada berkas klaim tersebut masih terdapat kesalahan pengimputan, kendala lain berupa bukti tindakan medis yang tidak lengkap...." (KLI 32 Tahun)

"," Walaupun sudah dajukan oleh RS, 
namun masih terdapat pengembalian berupa perbaikan mislanya hasil pemeriksaan penunjang medis tidak dilampirkan, ketidaksesuaian koding..." (SDY 24 Tahun)

",, Bila masih terdapat kekurangan berkas, maka kami di BPJS akan melakukan koordinasi dengan RS untuk melakukan perbaikan berkas tersebut. Umunya hasil pemeriksaan penunjang medis tidak dilampirkan, ketidaksesuaian koding, dan berkas resume medis yang tidak lengkap ...." (DYK 39 Tahun)

Tujuan pelayanan kesehatan yang diselenggarakan oleh rumah sakit pada hakikatnya adalah mengatasi permasalahan kesehatan yang dihadapi oleh masyarakat dan meningkatkan derajat kesehatan. Tujuan ini tertuang dalam rencana strategis rumah sakit kearah terwujudnya pembangunan kesehatan jangka menengah dan jangka panjang dengan mengedepankan pelayanan kesehatan yang mudah, murah, dan bermutu.

Untuk mencapai tujuan pelayanan rumah sakit maka pihak penyelenggara RS harus menetapkan target pelayanan yang objektif, jelas, terukur dan spesifik dengan mengutamakan optimalisasi pelayanan secara cepat dan berkesinambungan. Demi mewujudkan pelaksanaan fungsi-fungsi pelayanan administrasi rumah sakit dengan baik, maka salah satu point penting yang harus diperhatikan adalah efektifitas pelayanan klaim JKN untuk mencegah terganggunya siklus keuangan rumah sakit.

Peningkatan mutu dan Kepuasan pelayanan RS berkaitan erat dengan perbaikan manajemen keuangan rumah sakit, karena fungsi-fungsi pelayanan dapat berjalan dengan baik, membutuhkan sumber daya keuangan yang memadai dan dana yang cukup. Dengan adanya system klaim yang tertunda maka akan menggangu manajemen dan perencanaan keuangan RS, menghambat pelayanan yang berdampak buruk pada rendahnya mutu pelayanan dan rendahnya kinerja rumah sakit.

Peran petugas sangat penting di dalam pengelolaan system klaim JKN Rumah sakit. Para petugas yang diberi tanggung jawab baik tenaga medis dan tenaga adminstrasi pengelola klaim JKN harus memiliki keahlian dan pengetahuan yang cukup sehingga ketersediaan dokumen berkas klaim menjadi tanggungjawab mereka untuk selalu disiapkan dan dipertanggungjawabkan setiap saat ketika dibutuhkan. Pengetahuan petugas akan batas waktu penyetoran berkas di kantor BPJS menjadi acuan bagi petugas klaim untuk menyiapkan dokumen berkas klaim sebelum batas waktu tersebut berakhir, hal ini berkaitan dengan pelaksanaan verifikasi dokumen oleh petugas BPJS sebelum kegiatan pencairan dana klaim dilakukan. Oleh karena itu petugas yang ditempatkan pada bagian pengelolaan klaim wajib mengikuti dan mempelajari informasi yang terkait dengan pengelolaan klaim JKN sehingga ketentuan dalam klaim dapat dikerjakan dengan baik utamanya batas waktu penyetoran berkas klaim tersebut, sebab hal ini dilakukan mengingat beberapa petugas terkait pengelolaan klaim belum mengetahui batas waktu pengumpulan berkas klaim.

Pengelolaan klaim JKN di rumah sakit menjadi suatu keharusan yang perlu dikerjakan oleh petugas kesehatan RS. Sistem pembiayaan pelayanan kesehatan selain bersumber dari pemerintah juga bersumber dari masyarakat. BPJS kesehatan sebagai lembaga pengelola dana JKN, memiliki koordinasi yang erat dengan RS dalam pembayaran klaim pelayanan kesehatan yang telah diajukan oleh RS. Kaitan dalam pengelolaan klaim JKN, kedua lembaga tersebut melaksanakan fungsi pelayanan administrasi Klaim JKN dengan berpedoman pada ketentuan dan peraturan yang ada untuk dipatuhi bersama. Setelah RS memberikan pelayanan kesehatan kepada masyarakat, maka RS akan mengajukan klaim JKN ke kantor BPJS kesehatan untuk mendapatkan penggantian dana atas pengeluaran operasionalisai pelayanan kesehatan. Mekanisme pengajuan dan pembayaran klaim dana JKN yang diajukan RS terlebih dahulu dilakukan verifikasi dokumen untuk dilakukan pengecekan kebenaran dan objektifitas administrasi dan medis yang telah dilakukan RS. Persyaratan dokumen klaim harus memenuhi kelengkapan termasuk persyaratan yang telah ditetapkan dalam juknis klaim. Bila usulan dokumen berkas klaim tidak sesuai dengan yang telah ditetapkan dalam juknis, maka pihak BPJS wajib memberikan koreksi untuk dilakukan perbaikan oleh pihak RS sebelum pembayaran klaim di lakukan.

Berdasarkan fakta yang terjadi di RS, bahwa dokumen berkas klaim sering kali mengalami keterlambatan atau tidak tepat waktu ketika diajukan ke pihak BPJS, hal ini mengindikasikan masih terdapat permasalahan dalam pengelolaan berkas klaim JKN. Fakta tersebut tergambarkan dari pihak rumah sakit belum optimal di dalam menyediakan dan mengelola klaim JKN. Bila kondisi ini terus berulang kejadianya maka akan berdampak pada RS. Dampak besar yang dapat terjadi yaitu siklus keuangan RS terganggu, operasionalisasi pelayanan terhambat dalam 
memenuhi kebutuhan pelayanan kesehatan masyarakat, dan pada keadaan yang lebih tinggi dapat menyebabkan kematian pasien bila pelayanan tidak dapat disediakan oleh RS.

Secara faktual dilapangan diperoleh bahwa faktor penyebab ketidaktepatan waktu pengajuan klaim JKN oleh RS dapat dilihat Dari sisi sumber daya brain Ware dalam hal ketersediaan tenaga yang cukup, keahlian/kompetensi tenaga, beban kerja, kesibukan petugas, dan kurangnya pelatihan petugas. Dari sisi sumber daya software dalam hal ini adanya gangguan aplikasi, jaringan selalu ngadat, dan waktu perbaikan instalasi yang tidak menentu. Dari sisi Hard Ware perangkat komputerisasi mengalami kerusakan. Dari sisi Pasien kelengkapan berkas pasien tidak ada atau terlambat diserahkan kepada petugas. Bila kondisi ini terus terjadi maka akan menghambat pengajuan klaim, pembayaran klaim akan tertunda. Dampak yang dirasakan dalam pelayan Rumah Sakit adalah pelayanan terhambat, mutu rendah, kesulitan keuangan RS, kepuasan pasien, kinerja RS rendah, dan dampak besar nya yang terjadi adalah derajat kesehatan tidak akan terwujud. Upaya yang harus dilakukan adalah pelaksanaan pelatihan, perbaikan system software, sosialisasi ke pasien, pengawasan, koordinasi dan kerjasama tim antara RS dan BPJS secara berkesinambungan.

Hal ini sejalan dengan hasil penelitian ${ }^{10}$ yang mengatakan bahwa Faktor penyebab keterlambatan klaim Asuransi Jamkesmas di RSUD Wonosari adalah kesibukan dokter dalam pelayanan, kesadaran perawat, kapasitas tenaga tidak memadai, keahlian petugas, Hardware dan Software yang kurang memadai, dan kelengkapan dan kesalahan berkas Dokumen klaim. Temuan ${ }^{11}$ mengatakan bahwa Keterlambatan berkas verifikasi BPJS disebabkan oleh lambatnya pengisian rekam medis, lambatnya pengantaran berkas ke ruang Instalasi Jaminan Pembiayaan sehingga menyebabkan lambatnya pencairan dana JKN ke rumah sakit. Penelitian ${ }^{12}$ diperoleh bahwa faktor yang mempengaruhi klaim tertunda adalah ketidaklengkapan resume medis yang didominasi ketiadaan tanda tangan Dokter Penganggungjawab Pasien (DPJP) disebabkan didapatkan adanya tugas ganda pada case manager sehingga terjadinya keterlambatan dalam penyelesaian resume medis elektronik. Temuan ${ }^{13}$ mengatakan bahwa faktor penyebab keterlambatan klaim berasal dari faktor man adalah petugas verifikator kelengkapan awal, dokter, dan petugas pengodean. Faktor machine adalah karena SIMRS belum terintegrasi dengan INA-CBG. Methode adalah karena implementasi SPO yang belum lancar. faktor materials karena persyaratan yang tidak sesuai.
Pengembalian dokumen berkas klaim JKN oleh pihak BPJS setelah dilakukan verifikasi penting menjadi catatan untuk disajikannya dokumen yang valid, objektif dan dapat dipertanggungjawabkan secara administrative. Ketelitian dan ketegasan BPJS untuk mengembalikan berkas klaim yang bermasalah patut diterima dengan baik oleh RS untuk dilakukan perbaikan dokumen, hal ini akan membantu RS dalam penyusunan dokumen, menghindari kesalahan penulisan yang berulang, mencegah fraud, mencegah kepalsuan dokumen dan sebagainya. Upaya yang dilakukan untuk mengatasi hal tersebut adalah melalui pelatihan manajemen klaim, pengawasan, koordinasi dan evaluasi pelayanan

Hasil temuan wawancara mendalam diperoleh bahwa ketepatan waktu pengajuan klaim JKN sangat dipengaruhi oleh kelengkapan berkas klaim yang diajukan oleh RS. Kenyataan yang ditemukan bahwa Pihak Rumah Sakit seringkali belum menyelesaikan berkas Klaim JKN sampai batas waktu yang ditentukan. Ketidaklengkapan berkas klaim JKN berupa catatan medis hal ini disebabkan oleh dokter yang selalu menunda pekerjaan, beban kerja yang tinggi dan kesibukan dokter, termasuk faktor perawat yang lupa mengingatkan dokter untuk mengisi resume medis. Kurangnya kelengkapan berkas Klaim JKN dari ruang rawat inap disebabkan oleh ketidaktelitian perawat dalam pengecekan berkas klaim, demikian halnya keterlambatan pasien melengkapi berkas administrasi, kesalahan pengkodean dan gangguan jaringan internet. Adanya Pengajuan klaim JKN yang terlambat maka akan memperlambat pembayaran klaim JKN yang diajukan oleh RS. Dampak jangka panjang bagi rumah sakit akan memperburuk pelayanan kesehatan.

Hal tersebut sejalan dengan hasil penelitian ${ }^{14}$ yang mengatakan bahwa beberapa berkas yang tidak lengkap yaitu laporan individual pasien dengan persentase ketidaklengkapan $84 \%$. Laporan penunjang dengan persentase ketidaklengkapan $18 \%$ dan fotocopy kartu BPJS dengan persentase $7 \%$ ketidaklengkapan. Hasil penelitian ${ }^{15}$ mengatakan bahwa waktu penyelesaian 1 berkas klaim petugas verifikasi administrasi sampai berkas dientry membutuhkan waktu selama 18:39:03 per berkas. Kelengkapan persyaratan berkas klaim terdapat $35 \%$ persyaratan berkas klaim tidak lengkap dan harus dikembalikan lagi keruang perawatan, kembalinya berkas klaim ke ruang perawatan yang berpotensi menyebabkan keterlambatan dalam pengajuan klaim. Dilihat dari jumlah dan kompetensi sumber daya manusia petugas pengelolaan klaim berpotensi menyebabkan keterlambatan dalam pengajuan klaim dan masih 
ada beberapa petugas pengelolaan klaim yang masih belum mengikuti pelatihan yang sesuai dengan jabatannya. Hasil penelitian ${ }^{16}$ menemukan bahwa sebanyak 142 berkas klaim rawat inap dan 82 berkas rawat jalan yang dikembalikan. Alasan pengembalian karena tidak lolos verifikasi administrasi pelayanan dan verifikasi pelayanan kesehatan. Penyebab tidak lolos verifikasi terutama karena ketidaktelitian dari petugas pemberkasan dan adanya perbedaan persepsi tentang kode diagnosa antara Rumah Sakit Hermina Ciputat dengan BPJS Kesehatan.

\section{SIMPULAN}

Ketepatan waktu pengajuan klaim pelayanan kesehatan oleh Rumah Sakit Badan Layanan Umum Bahteramas Prov. Sulawesi Tenggara belum sepenuhnya berjalan optimal dilakukan sehingga kondisi ini dapat menghambat pengelolaan keuangan rumah sakit di masa datang.

\section{SARAN}

1. Hendaknya pihak rumah sakit melakukan pelatihan manajemen klaim JKN diikuti dengan pengawasan pengelolaan klaim, peningkatan sumber daya teknologi jaringan internet, serta peningkatan koordinasi pengelolaan klaim dengan pihak BPJS guna tercapainya efektifitas program JKN

\section{DAFTAR PUSTAKA}

1. BPJS, RI Kesehatan. Panduan Manual Verifikasi Klaim INA-CBG Edisi 1. Jakarta: Sekretariat Jampelkes, 2018.

2. Febriana, D. "Gambaran Pengelolaan Klaim Jaminan Kesehatan Nasional (JKN) Di Rumah Sakit Jiwa Dr. Soeharto Heerdjan." Fisip UI, 2014.

3. Ardithya, $\mathrm{T}$ Perry. "Faktor-Faktor Yang Melatarbelakangi Penolakan Klaim BPJS Oleh Verifikator BPJS di RSJ Dr. Amino Gondohutomo Provinsi Jawa Tengah Tahun 2015." Jurnal Fakultas Kesehatan Universitas Dian Nuswantoro Semarang, 2015.

4. Susan, Firsa O. "Analisis Administrasi Klaim Jaminan Kesehatan Nasional Rawat Jalan RSUD Kota Semarang Tahun 2016." Jurnal Kesehatan Masyarakat Volume 4 Nomor 4, 2016.

5. Noviatri, L W, dan Sugeng. “. Analisis Faktor Penyebab Keterlambatan Penyerahan Klaim BPJS di RS Panti Nugroho." Jkesvo (Jurnal Kesehatan Vokasional). Vol. 1 No 1, 2016.

6. Putra, W M. "Analisis Implementasi Kebijakan Jaminan Kesehatan Nasional di Rumah Sakit Umum Kota Tanggerang Selatan Tahun 2014." Skripsi, FKIK UIN Syarif Hidayatullah, 2014.
7. Tyas, A C. "Tinjauan Penyebab Adanya Ketidak Lengkapan Syarat Klaim BPJS di Unit Rawat Inap Rumah Sakit Bhakti Wira Tamtama Semarang." 2015.

8. RS BLUD Bahteramas Prov Sultra. Poril Rumah Sakit Badan Layanan Umum Daerah Bahteramas Prov Sulawesi Tenggara. Kendari, 2019.

9. Suhadi, Dkk. "Model Permasalahan Efektifitas Sistem Koordinasi Pelayanan Kesehatan Di Rumah Sakit Badan Layanan Umum Daerah Bahteramas Provinsi Sulawesi Tenggara." Preventif Journal Vol 4 (1), 2019: 31-35.

10. Suprapti, Aprillia. "Upaya Petugas Rekam Medis Menyelesaikan Keterlambatan Klaim Jamkesmas Di Rumah Sakit Umum Daerah Wonosari."

http://etd.repository.ugm.ac.id/home/detail_p encarian/70530, 2017.

11. Pradani, Estri Aditya, dan Lelonowati Dewi Sujianto. "Keterlambatan Pengumpulan Berkas Verifikasi Klaim BPJS di RS X: Apa Akar Masalah dan Solusinya ?" Jurnal Medicoeticolegal dan Manajemen Rumah Sakit. vol 6 (2), 2017: Hal 107-114.

12. Artanto, Antonius EP. "Faktor-Faktor Penyebab Klaim Tertunda BPJS Kesehatan RSUD Dr.Kanujoso Djatiwibowo Periode Januari - Maret 2016." Jurnal Administrasi Rumah Sakit Vol. 4 (2)., 2017: Hal 122-134.

13. Nugroho, Panti, Lenty Wahyu Noviatri, dan Sugeng. "Analisis Faktor Penyebab Keterlambatan Penyerahan Klaim BPJS di RS." Jurnal Kesehatan Vokasional Vol. 1 (1), 2016: Hal 22-26.

14. Linda, Megawati, dan Rita Dian Pratiwi. "Faktor-Faktor Penyebab Pengembalian Berkas Persyaratan Klaim BPJS Pasien Rawat Inap di RS PKU Muhammadiyah Yogyakarta." Jurnal Kesehatan Vokasional. Vol. 1 (1)., 2016: Hal 36-43.

15. Ayu Putri, Nevy Kusumaning, Karjono, dan Sendy Ayu Mitra Uktutias. "Faktor Penyebab Keterlambatan Pengajuan Klaim BPJS Kesehatan Pasien Rawat Inap." Jurnal Manajemen Kesehatan Yayasan RS. Dr. Soetomo Vol.5 (2)., 2019: Hal 134 - 143.

16. Supriadi, dan Syifa Rosania. "Tinjauan Berkas Klaim Tertunda Pasien JKN Rumah Sakit Hermina Ciputat 2018." Jurnal Vokasional Indonesia, Vol 7 (2), 2019: Hal 19-26. 